\title{
PERFORMANCE BASED EVALUATION OF FLAT SLAB STRUCTURES WITH SQUARE COLUMNS
}

\author{
Balesh.B.Koni ${ }^{1}$, S.S.Dyavanal ${ }^{2}$ \\ ${ }^{I}$ Post Graduate Student, Department of Civil Engineering, BVBCET, Hubli, Karnataka, India \\ ${ }^{2}$ Professor, Department of Civil Engineering, BVBCET, Hubli, Karnataka, India
}

\begin{abstract}
Most of the reinforced concrete structures comprise of conventional beam-column frames. In the present era, the multi-story structures are given higher priority with lack of availability of land. However, there are limits for the height and weight of the structures. Thus, the construction industry is more concentrated on measures to reduce the weight and height of the storey, without compromising with usable space. The flat slab structures serve the purpose as they are the structures involving slabs directly resting on columns; hence, negating the need for beams, which would consume lot of space and also lead to heavy weight of the structure. Even though, flat slabs are found to be advantageous in functional as well as economic aspects; the key issue with flat slabs is their inability to withstand lateral loads efficiently. In the present study, the seismic behaviour of flat slab structures is studied. The 7 storey building models involving flat slab without drops, with drops and with edge beams are modelled considering both bare frame and brick infill frame structures with square columns. The buildings are located in medium soil cover with seismic zone III. The analysis is performed using ETABS 2013 V13.2. The non-linear behaviour of the building models is studied by pushover analysis, considering FEMA 440 parameters. The prime emphasis is made to consider user defined hinge properties to establish the actual hinging pattern of the members. The performance of the building models is studied by evaluating the parameters like hinge locations, ductility ratio, safety ratio and global stiffness.
\end{abstract}

Keywords: Soft Storey, Infill, Flat Slabs, Pushover Analysis, Ductility, Stiffness, Performance Levels, Safety Ratio, User Defined Hinges

\section{INTRODUCTION}

Earthquake has been the prominent disaster since early era. But, the tendency and intensity of earthquakes is increasing with the global warming, pollution and depletion of earth. Previously many of the structures were built considering gravity loads only. Initially many structures were built with the infill masonry walls. The infill walls add up to stiffness of the building to some extent. Presently, bare framed structures are coming up, which prove to be weaker in withstanding lateral loads. With the growing need for safety anddevelopment, requires multi-storey structures to be designed with seismic considerations. Another problem of multi-storey structuresis their heavy weight. With increasing weight of the building, the cost offoundation increases. There are also certain bye-laws of Municipal Corporation restricting the height of building to certain limit. The beams add up greatly to the weight of building and consume most of the space. Thus the story height increases, thereby affecting space requirements and foundation costs. Hence, the thought of beamless structures came into light. These are also called as flat slabs. The flat slab structures may be classified into slabs without drops, with drops, with edge beams and with column heads. The ease of construction, better aesthetical look, reduction in storey height and reduction in weight are some of the key features of flat slab structures. But, the flat slabs have proved to be weak in withstanding the seismic loads coming on it, due to their higher flexibility.
The aim of this paper is to study the performance of various flat slab structures located in seismic zone III and medium soil cover. The pushover method of analysis with FEMA 440 parameters is considered for the analysis in ETABS 2013 V13.2.

There are many studies carried out on seismic behaviour of pushover analysis. Dhananjay D. J. and Pranesh B. M.(2013) found that the displacement at performance point for flat slab is $48 \%$ higher compared to conventional slabs [16]. SahanaPonnamma T.D. et al. (2015) concluded that the percentage difference in the base shear and displacement of conventional slab and flat slab with outrigger at mid height were $6.9674 \%$ and $2.4 \%$ respectively [17].Gouramma G. and Jagadish K. G. (2015) observed that the base shear of flat slab at performance point was around $60 \%$ less than conventional slab and displacement was $35 \%$ more than conventional slab [18].Anuj B. andAditi P. (2016) concluded that the base shear of flat slabs was almost similar to that of grid slabs but displacements of flat slabs were more comparatively [19].Amit A. S. and Deotale R.S (2012) studied the cost comparison of flat slab models without drop, with drop and with edge beams and grid slabs. It was observed that the models with drops were efficient and economic [20]. Mehmet I. and Hayri B.O. (2006) found that user defined hinge properties are more effective in resembling the actual behaviour of plastic hinge formation [21]. 


\subsection{Modeling of Flat Slabs}

The flat slabs are divided into two strips, namely column strip and middle strip for the purpose of design. They are defined as follows,

Column strip: It is the strip comprising junction of column with slab. The width of this strip is 0.75 times the span in that direction. Column strip is designed to carry $75 \%$ of the negative bending moment at interior span and all the negative moment developed in the exterior zone. It is also designed to carry $60 \%$ of the total positive bending moment in the panel.

Middle strip: Middle strip is the strip at the midst of the span comprising 0.25 times the span. Middle strip is designed to carry the portion of bending moment not carried by the column strip. Each middle strip is designed to carry sum of bending moment to be carried by two half of the strip.

\subsubsection{General Design Considerations}

Thickness of flat slabs: The flat slab thickness should be as per span to effective depth ratios as mentioned in clause 23.2 of IS456, 2000. For slabs with Drops confirming to 3.3.4.2, the same procedure of proportioning can be considered as per clause 23.2. If the conditions are not satisfied, then the span to effective depth ratios obtained as per clause 23.2 should be multiplied by a factor 0.9 . The larger span is considered in this case. The code also recommends that the thickness of flat slab shall not be less than $125 \mathrm{~mm}$.

Specifications for Drop: The Drops should be rectangular in plan and their length in each direction should not be less than one third of the span in that direction. In case of exterior panels, the width of the drop from centre of edge column should be half of the width of drop at interior panels. The minimum thickness of Drops should be more than one quarter of thickness of slab and not less than $100 \mathrm{~mm}$.

\subsubsection{Moment and Shear Transfer between Slabs and Columns}

The stiffness of slab-column decides the strength of slab in sustaining the loads. The load is transferred in the form of shear from slab to column. The moments are transferred in addition to the shear and moments tend to be critical at the exterior columns. The column lateral reinforcement is based on the shear forces arising from the moment transfer.

\section{DESCRIPTION OF THE MODEL}

In the present study, three dimensional 7 storey RC flat slab building models are considered. The specifications of the flat slab models are considered from IS456: 2000[12]. The Fig. 1 to Fig. 5 show the plans and elevations of the building models considered for the study. The building models are regular with four numbers of bays in both longitudinal and lateral directions, with each span being $6 \mathrm{~m}$. The projection of flat slabs beyond the edge columns is $0.3 \mathrm{~m}$. The level of plinth from the foundation is $2 \mathrm{~m}$ and the height of all other storeys is $3 \mathrm{~m}$, for all the building models in the study. The seismic zone, prior to the location of buildings is zone III, with seismic zone factor 0.16, as per IS 1893(Part 1): 2002[13]. Masonry brick infill walls are modelled as equivalent diagonal strut [3]. The Moment hinge ' $M$ ', axial force and moment hinge 'PM', and axial force hinge ' $\mathrm{P}$ ' with frame nonlinear hinge properties are assigned to both the ends of frames, considering user defined hinge properties into account.

The following flat slab models are considered for the study, Model 1: Flat slab without drops

Model 2: Flat slab with drops

Model 3: Flat slab with edge beams

The above three models are further modelled as bare frame and infill frame building models. The infill frame models comprise of a soft storey at ground level.

The density of concrete is $25 \mathrm{kN} / \mathrm{m}^{3}$. Elastic modulus of concrete is $25000 \mathrm{MPa}$. The steel grade of Fe-415 and concrete grade of M25 are considered. Poisson's ratio of concrete is 0.2 . The size of beams is $300 \mathrm{~mm}$ by $500 \mathrm{~mm}$. The square columns of size $500 \mathrm{~mm}$ by $500 \mathrm{~mm}$ are provided. The flat slab thickness is $200 \mathrm{~mm}$. The drops are of size $3 \mathrm{~m}$ by $3 \mathrm{~m}$ in plan and thickness of $350 \mathrm{~mm}$.

The Live load of $3 \mathrm{kN} / \mathrm{m}^{2}$ and Floor finish of $1 \mathrm{kN} / \mathrm{m}^{2}$ are considered. All the models are designed for 1.2(DL+LL+EQ) and 1.2(DL+LL+RS) load combinations.

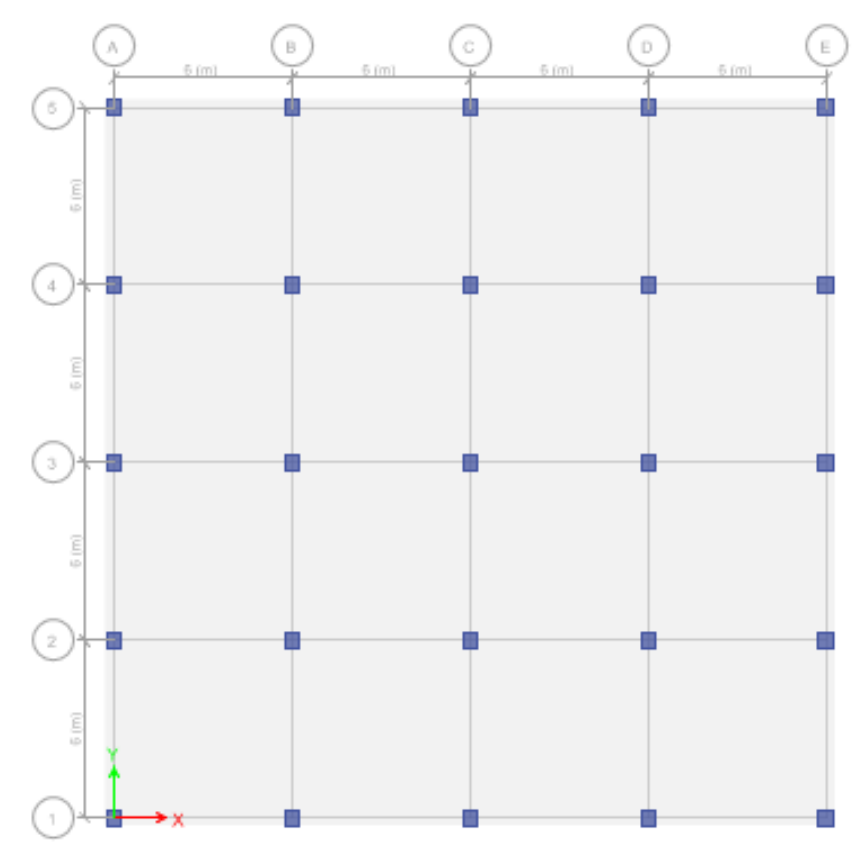

Fig-1: Plan of building model 1 


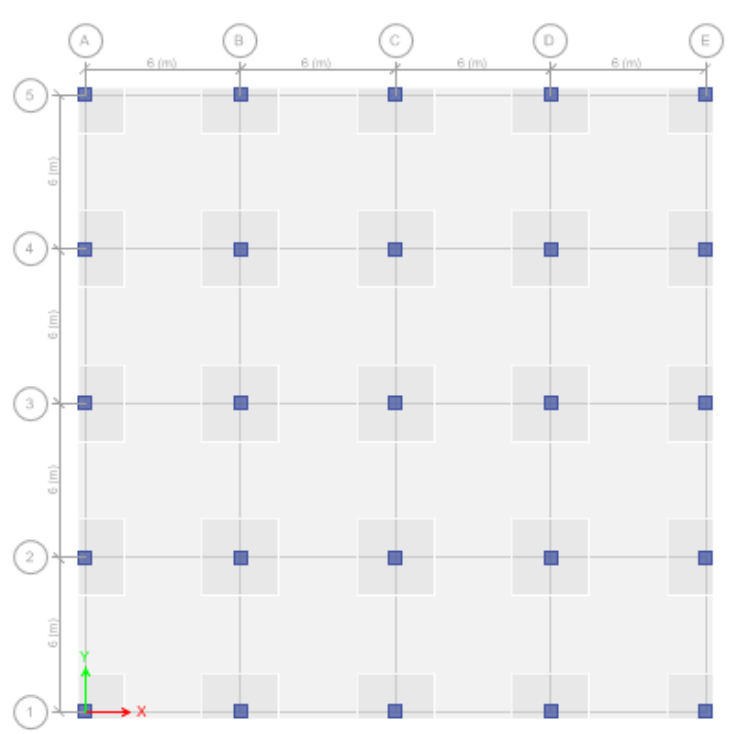

Fig-2: Plan of building model 2

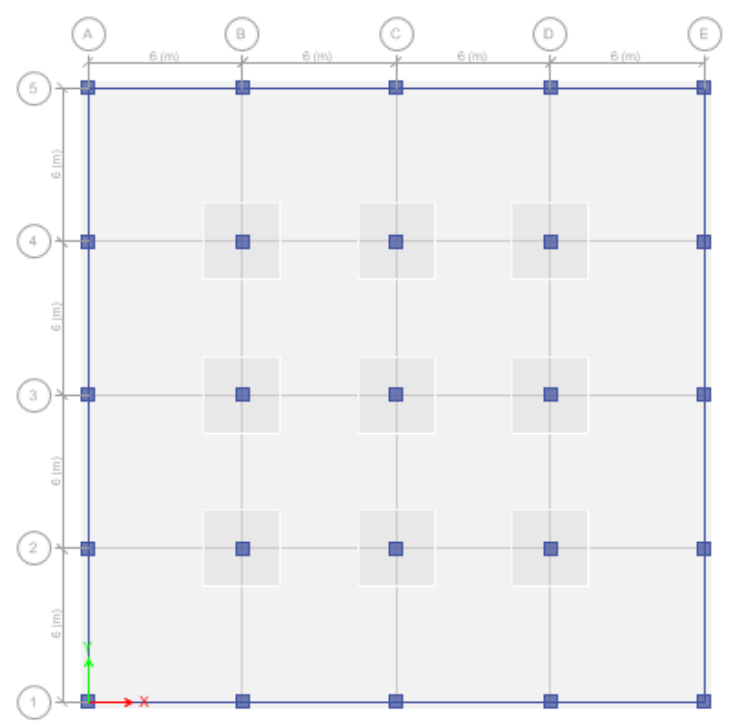

Fig-3: Plan of building model 3

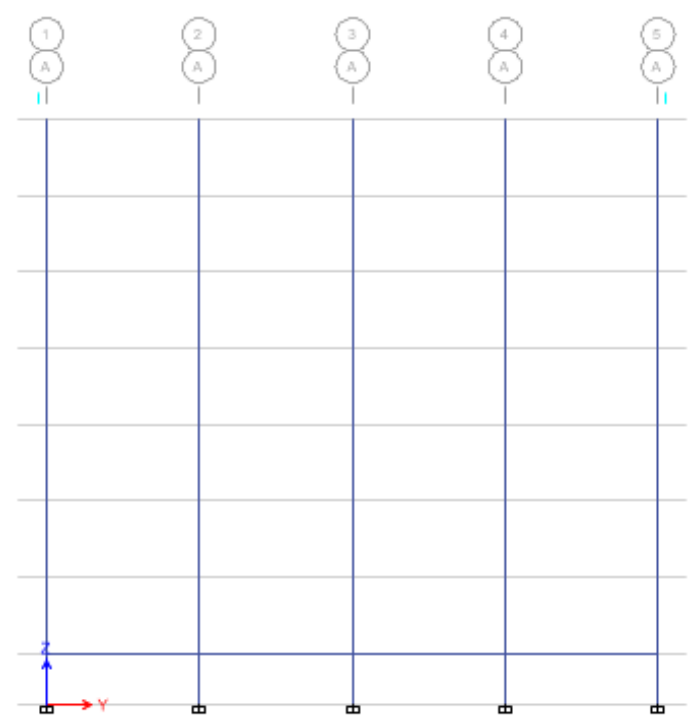

Fig-4: Elevation of 7 storey bare frame building model

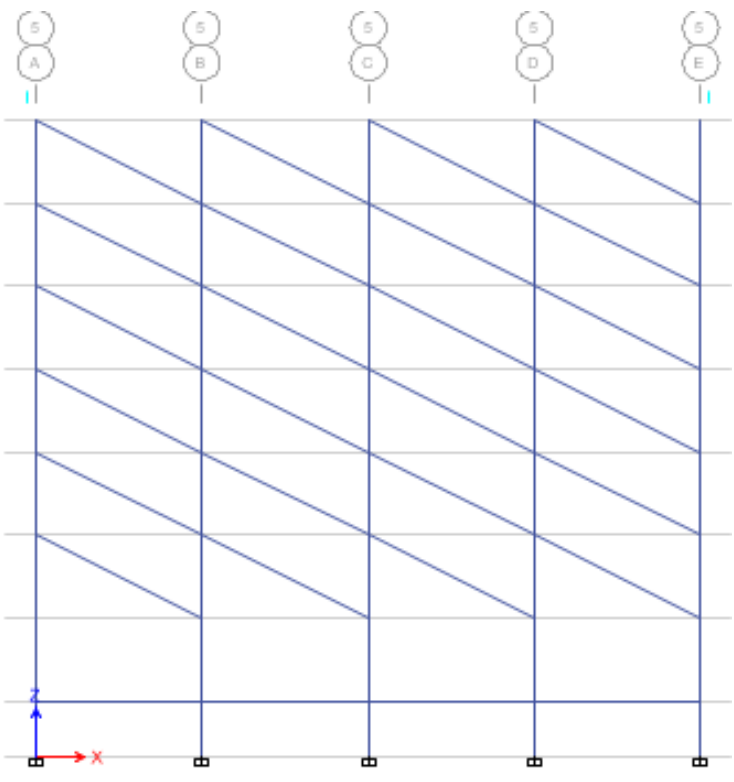

Fig-5: Elevation of 7 storey infill frame building model with a soft storey

\section{METHODOLOGY OF THE STUDY}

\subsection{User Defined Hinges}

The pushover analysis involves definition of momentcurvature relation for beams and columns; and also loaddeformation relation for equivalent strut elements. These relations are usually inbuilt in ETABS and SAP software as default hinge properties. However, these properties do not resemble the actual behaviour of sections in the study. Thus, user defined hinge properties have gained importance for representing actual hinging criteria. This paper considers user defined hinge properties with Moment hinges $\left(\mathrm{M}_{3}\right)$ assigned for beams, axial load- moment $\left(\mathrm{P}-\mathrm{M}_{3}\right)$ hinges for columns and axial load (P) hinges for struts. The hinge length of 0.1 is generally assigned.

\subsubsection{Moment-Curvature for Beam Section}

The moment curvature relationship for beam section is established by determining the maximum depth of neutral axis, dividing it into certain number of equal lamina and thereby obtaining the corresponding strain, moment and curvature [4]. The moment and curvature are then divided by the scale factor. Scale factor for moment is obtained by dividing the moment by yield moment. The scale factor for curvature is usually taken as unity. The curve is plotted illustrating the relation between moment and curvature. The present study considers the recommendations of IS 456: 2000 [12] to obtain moment- curvature relation.

The moment-curvature relation for the beam section $300 \mathrm{~mm}$ by $500 \mathrm{~mm}$ is shown in Chart 1 . 


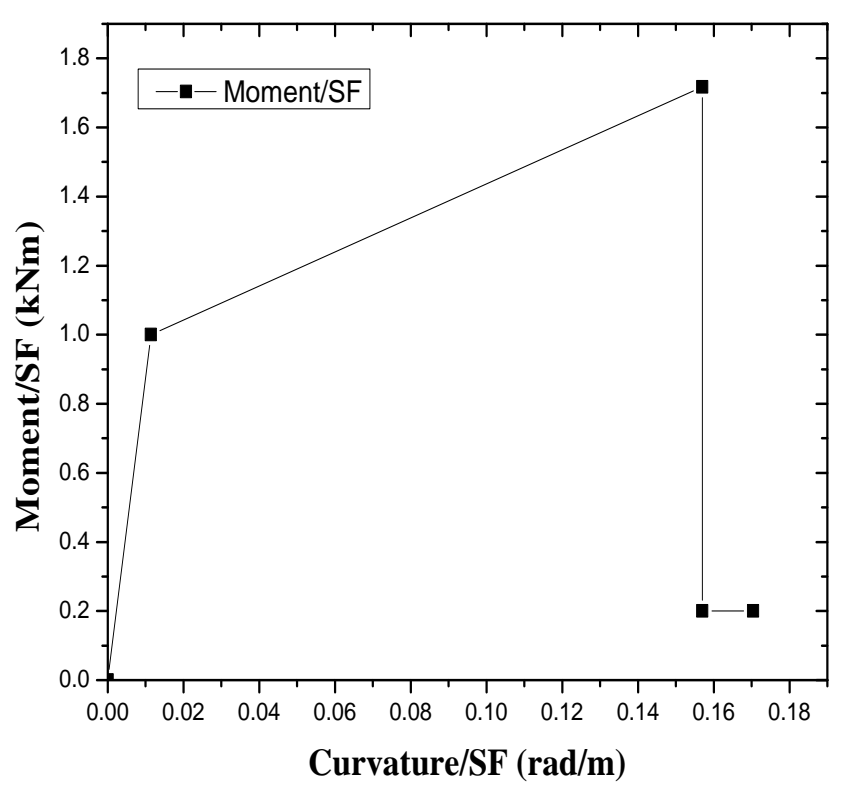

Chart-1: Moment-curvature relation for beam section $300 \mathrm{~mm}$ by $500 \mathrm{~mm}$

\subsubsection{Moment Curvature Relation for Column}

\section{Section}

The columns may be short, long or slender. The specifications for determination of type of column are specified in IS 456: 2000[12]. In the present study, all the columns are short. The axial load and moment hinges properties are determined by moment-curvature relation and P-M interaction curve. The columns may be further analyzed for two cases,namely, neutral axis lying outside the section and neutral axis lying inside the section.

The moment curvature and P-M interaction relations involve determination of maximum depth of neutral axis, subdividing the neutral axis length into various lamina of equal interval, setting axial load to zero initially, recording corresponding neutral axis depth, strains, moment and curvature. The axial load is then increased up to the point where moment in the column is zero. The corresponding neutral axis depth, strains and curvature are determined for all the points.

The present work, considers the column sizes of $500 \mathrm{~mm}$ by $500 \mathrm{~mm}$, for which P-M interaction curve and momentcurvature relations obtained are shown in Chart 2 and Chart 3 , respectively.

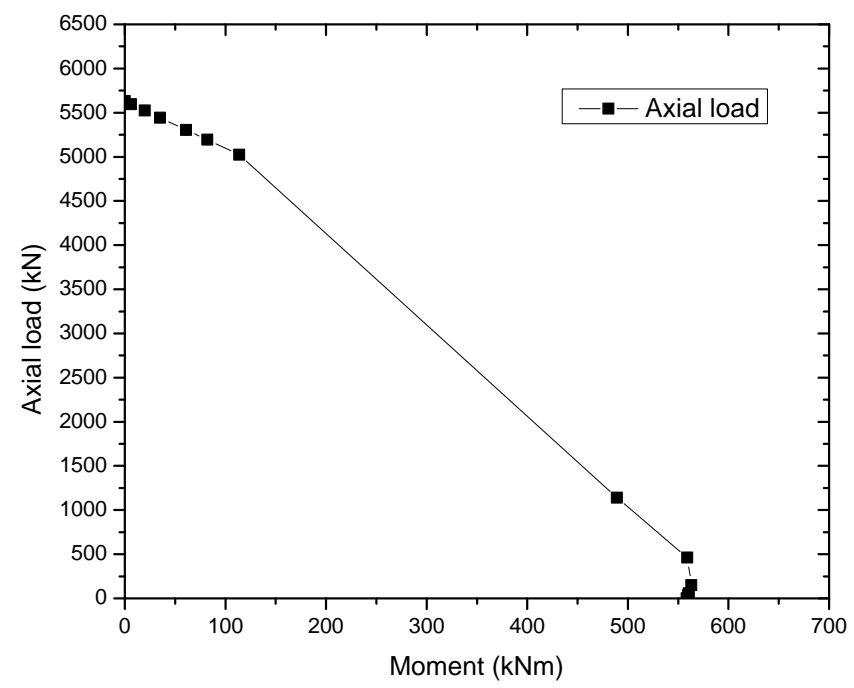

Chart-2: P-M interaction curve for column section $500 \mathrm{~mm}$ by $500 \mathrm{~mm}$

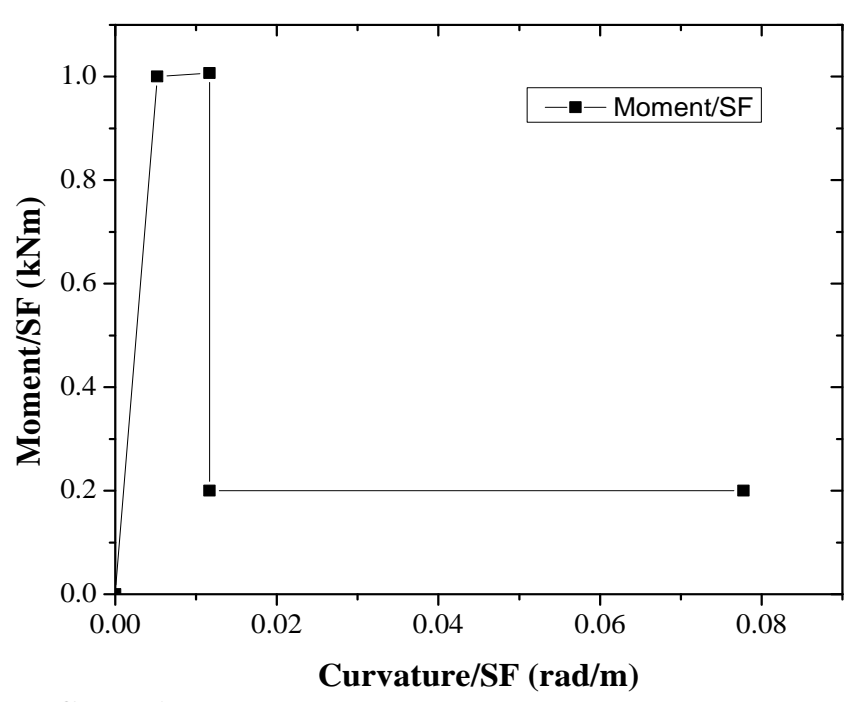

Chart-3: Moment curvature curve for column section $500 \mathrm{~mm}$ by $500 \mathrm{~mm}$

\subsubsection{Load-Deformation Curve for Brick Infill}

The definition of user defined axial hinges for brick infill walls defined as equivalent struts in ETABS 2013, requires data for load-deformation curve. The prism of brick masonry is constructed and tests are carried out in order to evaluate performance of the masonry material.

Laboratory test results obtained from the previous study are considered for the uniaxial load deformation curve of prism of masonry [3]. The tests were carried out on locally available bricks with approximate length of $230 \mathrm{~mm}$, width $110 \mathrm{~mm}$ and thickness $75 \mathrm{~mm}$. Strong mortar mix of $1: 3$ and ordinary Portland cement 43 grade of Jindal steel works were used for making of bricks. The bricks were subjected to uniformly distributed load by testing them in universal testing machine with $1000 \mathrm{kN}$ capacity. Totally, 4 brick masonry panels of size $600 \mathrm{~mm}$ by $600 \mathrm{~mm}$ by $75 \mathrm{~mm}$ were prepared and tested in UTM to get the performance states of the masonry. The mean results of the load-deformation data are shown in Chart 4. 


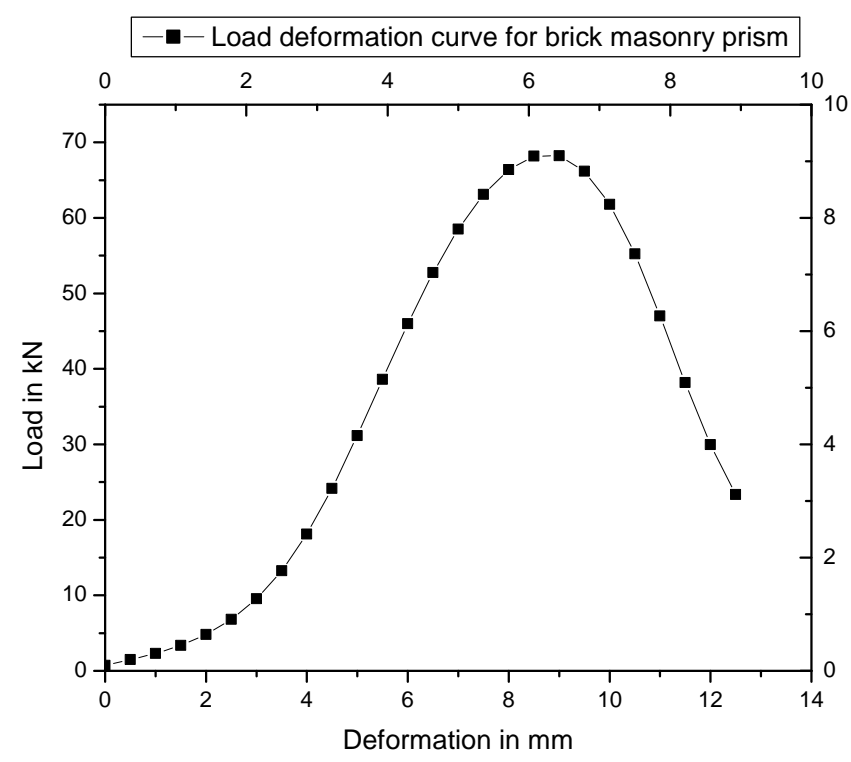

Chart-4: Mean results of load deformation curve for the prism of brick masonry

\subsection{Pushover Analysis}

Pushover method of analysis is a non-linear static method, which involves displacement of the building sideways by applying monotonously increasing lateral load throughout the height of the structure. The pushover method consists of two types of analysis, namely, Force controlled method and Deformation controlled method. The force controlled method considers defining a specified target lateral load, and studying the deformation of the structure. The deformation controlled method considers setting a target displacement for the structure and proportionally increasing lateral load until the target displacement is reached. The target displacement of $4 \%$ of the height of building is recommended by FEMA 273 [10].The roof displacement is plotted versus the base shear to obtain global capacity curve. The Pushover analysis method is said to be approximate as there are lots of assumptions made, such as target displacement, time period, etc. In force-controlled pushover procedure some numerical problems affect the accuracy of results since target displacement may involve a very small positive or even a negative lateral stiffness because mechanisms and P-delta effects are developed.

The Pushover curve is split into various performance levels, namely, Immediate occupancy level, Life safety level, Collapse prevention level, Collapse and structural stability. The performance of the building is measured at a performance point, obtained by intersection of demand spectra and capacity curve. The present study considers FEMA 440 [8] parameters for the pushover analysis of the building models.

\section{RESULTS AND DISCUSSIONS}

\subsection{Performance Evaluation of Building Models}

The performance of all the models is studied by pushover analysis. The results of pushover analysis with equivalent static and response spectrum load cases are discussed in this section.

\subsection{Hinge Locations at Various Performance Levels}

The hinge locations at initial and collapse yield, and their corresponding base shear and displacements are presented in Table1 to Table 4.

Table-1: Hinge locations for 7 storey bare frame building models by pushover analysis with equivalent static load case

\begin{tabular}{|c|c|c|c|c|c|c|c|c|c|c|}
\hline \multirow{2}{*}{ Model No. } & \multirow{2}{*}{\multicolumn{2}{|c|}{ Displacement (mm) }} & \multirow{3}{*}{$\begin{array}{l}\text { Base force }(\mathbf{k N}) \\
3311.22\end{array}$} & \multicolumn{7}{|c|}{ Hinge Locations } \\
\hline & & & & A-B & B-IO & IO-LS & LS-CP & CP-C & C-D & Total \\
\hline \multirow{2}{*}{1} & Yield & 36.3 & & 223 & 107 & 0 & 0 & 0 & 0 & 330 \\
\hline & Ultimate & 151 & 4197.7 & 216 & 33 & 2 & 49 & 0 & 30 & 330 \\
\hline \multirow{2}{*}{2} & Yield & 37.8 & 3740.81 & 232 & 98 & 0 & 0 & 0 & 0 & 330 \\
\hline & Ultimate & 141.9 & 4220.8 & 227 & 24 & 0 & 50 & 0 & 29 & 330 \\
\hline \multirow{2}{*}{3} & Yield & 34 & 3498.58 & 496 & 127 & 27 & 0 & 0 & 0 & 650 \\
\hline & Ultimate & 148.4 & 4504.99 & 492 & 76 & 13 & 25 & 0 & 44 & 650 \\
\hline
\end{tabular}

Table-2: Hinge locations for 7 storey infill frame building models by pushover analysis with equivalent static load case

\begin{tabular}{|c|c|c|c|c|c|c|c|c|c|c|}
\hline \multirow{2}{*}{ Model No. } & \multirow{2}{*}{\multicolumn{2}{|c|}{ Displacement (mm) }} & \multirow{2}{*}{ Base force $(k N)$} & \multicolumn{7}{|c|}{ Hinge Locations } \\
\hline & & & & A-B & B -IO & IO-LS & LS-CP & CP-C & C-D & Total \\
\hline \multirow{2}{*}{1} & Yield & 47.5 & 3880.07 & 632 & 88 & 0 & 0 & 0 & $\mathbf{0}$ & 720 \\
\hline & Ultimate & 143 & 4214.98 & 630 & $\mathbf{0}$ & $\mathbf{0}$ & 11 & 5 & 74 & 720 \\
\hline \multirow{2}{*}{2} & Yield & 41.8 & 3874.98 & 632 & 88 & $\mathbf{0}$ & $\mathbf{0}$ & $\mathbf{0}$ & $\mathbf{0}$ & 720 \\
\hline & Ultimate & 141.3 & 4224.31 & 628 & $\mathbf{0}$ & $\mathbf{0}$ & 4 & 2 & 84 & 720 \\
\hline \multirow{2}{*}{3} & Yield & 52.9 & 4158.85 & 1176 & 95 & 9 & $\mathbf{0}$ & $\mathbf{0}$ & $\mathbf{0}$ & 1280 \\
\hline & Ultimate & 133.1 & 4512.89 & 1171 & 19 & $\mathbf{0}$ & 46 & $\mathbf{0}$ & 44 & 1280 \\
\hline
\end{tabular}


Table-3: Hinge locations for 7 storey bare frame building models by pushover analysis with response spectrum load case

\begin{tabular}{|c|c|c|c|c|c|c|c|c|c|c|}
\hline \multirow{2}{*}{ Model No. } & \multirow{2}{*}{\multicolumn{2}{|c|}{ Displacement (mm) }} & \multirow{2}{*}{ Base force $(\mathbf{k N})$} & \multicolumn{7}{|c|}{ Hinge Locations } \\
\hline & & & & A-B & B-IO & IO-LS & LS-CP & CP-C & C-D & Total \\
\hline \multirow{2}{*}{1} & Yield & 46.5 & 3441.88 & 409 & 71 & $\mathbf{0}$ & $\mathbf{0}$ & $\mathbf{0}$ & $\mathbf{0}$ & 480 \\
\hline & Ultimate & 158.1 & 4303.53 & 377 & 13 & 3 & 63 & 1 & 23 & 480 \\
\hline \multirow{2}{*}{2} & Yield & 56 & 4004.59 & 385 & 95 & $\mathbf{0}$ & $\mathbf{0}$ & $\mathbf{0}$ & $\mathbf{0}$ & 480 \\
\hline & Ultimate & 150.2 & 4326.03 & 381 & 9 & 0 & 48 & $\mathbf{0}$ & 42 & 480 \\
\hline \multirow{2}{*}{3} & Yield & 102.4 & 4234.15 & 901 & 139 & $\mathbf{0}$ & $\mathbf{0}$ & $\mathbf{0}$ & $\mathbf{0}$ & 1040 \\
\hline & ultimate & 177.4 & 4590.63 & 851 & 99 & 16 & 30 & $\mathbf{0}$ & 44 & 1040 \\
\hline
\end{tabular}

Table-4: Hinge locations for 7 storey infill frame building models by pushover analysis with response spectrum load case

\begin{tabular}{|c|c|c|c|c|c|c|c|c|c|c|}
\hline \multirow{2}{*}{ Model No. } & \multirow{2}{*}{\multicolumn{2}{|c|}{ Displacement (mm) }} & \multirow{2}{*}{ Base force $(\mathrm{kN})$} & \multicolumn{7}{|c|}{ Hinge Locations } \\
\hline & & & & A-B & B-IO & IO-LS & LS-CP & CP-C & C-D & Total \\
\hline \multirow{2}{*}{1} & Yield & 39.2 & 3970.03 & 630 & 90 & $\mathbf{0}$ & $\mathbf{0}$ & 0 & $\mathbf{0}$ & 720 \\
\hline & Ultimate & 135.96 & 4312.51 & 630 & $\mathbf{0}$ & $\mathbf{0}$ & 7 & $\mathbf{0}$ & 83 & 720 \\
\hline \multirow{2}{*}{2} & Yield & 34.7 & 3968.22 & 630 & 90 & $\mathbf{0}$ & $\mathbf{0}$ & $\mathbf{0}$ & $\mathbf{0}$ & 720 \\
\hline & Ultimate & 132.5 & 4321.8 & 630 & $\mathbf{0}$ & $\mathbf{0}$ & 40 & 2 & 48 & 720 \\
\hline \multirow{2}{*}{3} & Yield & 47.1 & 4274.06 & 1176 & 93 & 11 & $\mathbf{0}$ & $\mathbf{0}$ & $\mathbf{0}$ & 1280 \\
\hline & ultimate & 125.5 & 4633.13 & 1171 & 19 & $\mathbf{0}$ & 43 & 2 & 45 & 1280 \\
\hline
\end{tabular}

In all the models, the base shear was the maximum in models with edge beams. The models without drops resulted in least base shear. Among bare frame models, the provision of drops didn't have much effect on base shear, however the reduction in displacement is observed to be $11.4 \%$. The edge beams increased base shear by $6.39 \%$. There is no much difference in base shears of bare frame and infill frames, but the displacement in infill frame models is $24 \%$ to $38 \%$ lower than bare frame models.

The hinges lying within life safety level for bare frame models 1,2 and 3 are $82.08 \%, 82.25 \%$ and $92.88 \%$, respectively. The hinges lying within life safety level for infill frame models 1,2 and 3 with square columns are $87.5 \%, 87.72 \%$ and $92.97 \%$, respectively. The results are almost similar in both equivalent static and response spectrum load cases. Hence, it is found that formation of hinges is almost similar in models 1 and 2; but the model 3 showed less number of hinges reaching collapse state. Thus, edge beams had a better impact on reduction of plastic hinge deformation.

\subsection{Ductility Ratio}

Ductility ratio is defined as the ratio of displacement at collapse yield or ultimate point to the displacement at initial yield [15]. This factor is very important parameter in studying the behaviour of structure in the inelastic state of failure. The ductility ratio depends on many factors such as material properties, geometric uniformity of the structure, loading rate, temperature, brittle nature of some members, joints and concentration of stresses. The code specifies minimum ductility of 4, allowing structure to deflect laterally, to avoid uneconomic design of members for higher stresses arising due tohigh stiffness. The ductility ratio is based on the collapse level, which is uncertain due to uncertainty of the earthquakes.
The structures are classified based on the various design levels of ductility,

- Structure responding elastically, ductility ratio, $\mu=1$

- $\quad$ Structure responding in ductile passion, $\mu>1$

The structures can also be designed based on the extent of ductility, as

- $\quad$ Structures with full ductility, $4<\mu<8$

- $\quad$ Structures with limited ductility, $1.5<\mu<4$

In this study, the ductility parameters of all the building models are studied by performing pushover analysis for equivalent static and response spectrum load cases. The ductility capacity of the buildings is equivalent to the response reduction factor of 5 . The ductility demand of models should be maintained less than the capacity. The Fig.10 to Fig.11presents the ductility ratios of all the models.



Fig-10: Ductility ratio for seven storey building models by equivalent static pushover analysis 


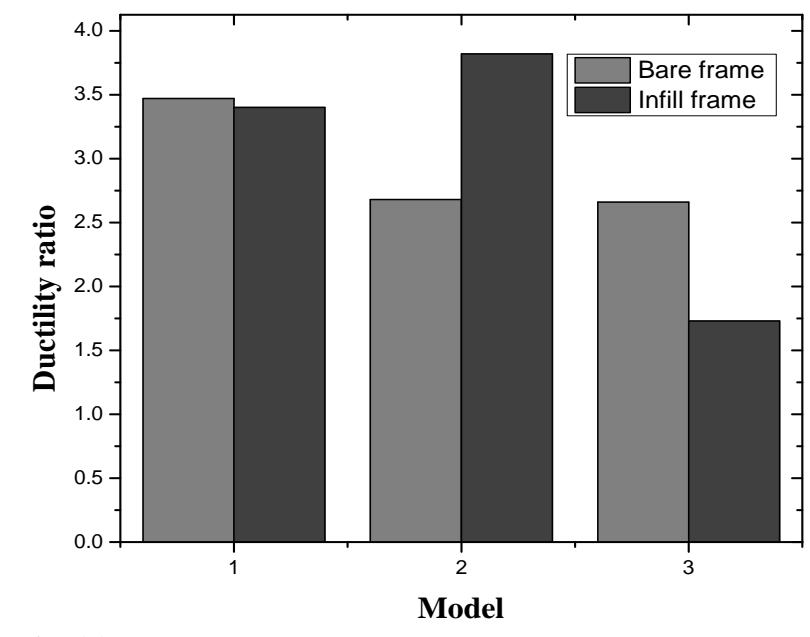

Fig-11: Ductility ratio of seven storey building models by response spectrum pushover analysis

It is observed from Fig.10 and Fig.11 that the models with drops are found to be $15 \%$ more ductile in presence of infill walls. However, the infill walls reduced the ductility of model 1 and model 2 by $2.5 \%$ and $22 \%$, respectively. The ductility of flat slabs is reduced by $23 \%$ to $50 \%$ by edge beams. The drops reduced ductility in bare frame models by $4 \%$ to $21 \%$. All the models are found to be having limited ductility. However, flat slab without drops models showed higher ductility than the other two models. The edge beams and drops reduce the ductility due to their higher stiffness. The brick infill also increased the stiffness, thereby hindering the ductility.

\subsection{Safety Ratio}

Safety ratio is the ratio of base shear at performance point to the base shear obtained by equivalent static method. The safety ratio is an important parameter to check the safety of the structure against earthquake loads. The building is said to be unsafe if the safety ratio is less than 1 , safe if it is equal to 1 and over safe if the ratio is more than 1 . Usually, there is a tendency of designing the structure to be over safe, as the earthquake loads cannot be predicted. The safety ratio obtained for the models under consideration is presented in Fig. 12.

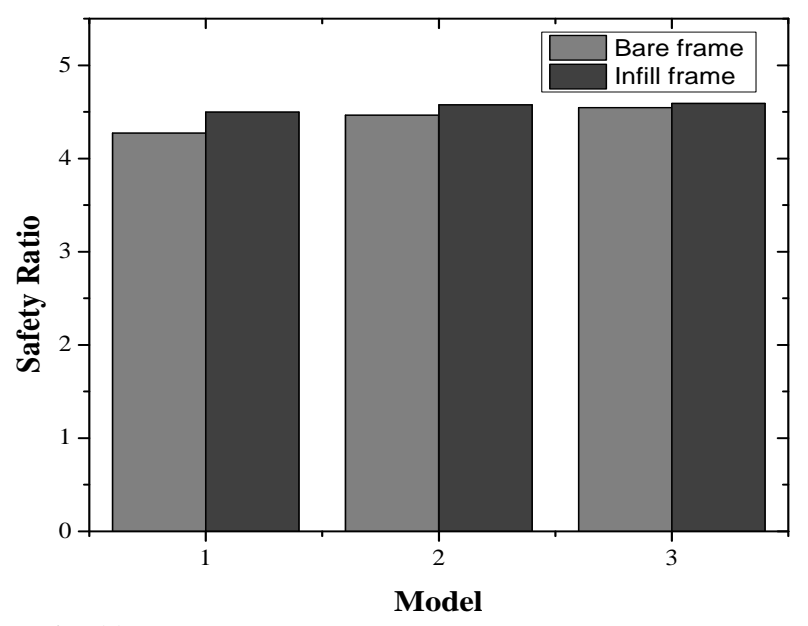

Fig-12: Safety ratio for seven storeybuilding models
It is observed from Fig. 12 that the safety ratio of model 2 is observed to be $4.45 \%$ higher than model 1 and that of model 3 is $6.32 \%$ higher than model 1 in case of bare frame models. The safety ratio is observed to be enhanced by $5.38 \%, 2.69 \%$ and $1.1 \%$ for model 1 , model 2 and model 3, respectively, with the provision of brick infill walls. Thus, it is found that safety of the building models increases with increase in the stiffness. The edge beams and drops provide sufficient stiffness to the models, hence higher safety. All the models in the study are found to be over safe.

\subsection{Global Stiffness}

Global stiffness is defined as the ratio of base force and displacement at performance point. Stiffness is a measure of deformations in the building. During lateral motion of the ground, the earthquake loads get more concentrated at weaker zones in the structure. The weaker zones may arise due to sudden variations in stiffness, strength and ductility of the structure. These weak zones fail to distribute loads evenly and lead to severe damage. Thus, structural engineer has to concentrate on keeping the variation in stiffness, strength and ductility, considerably low.The global stiffness of the structure can be improved by identifying the weak locations in the structure and taking proper measures to stiffen those zones.The global stiffness of the building models in this study, are presented in the Fig.13.

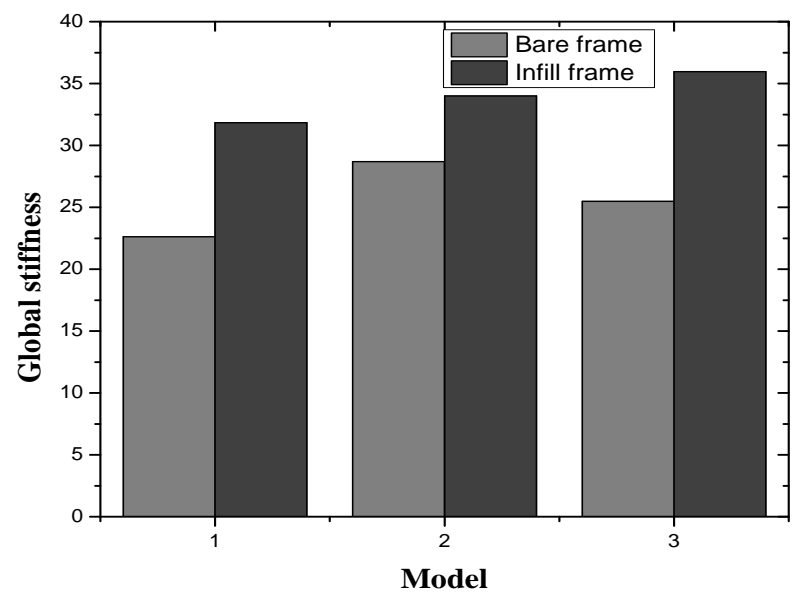

Fig-13: Global stiffness of 7 storey building models

It can be observed from the Table 11, that the global stiffness of model 2 is $26.89 \%$ higher than model 1 . Similarly, the global stiffness of model 3 is $12.65 \%$ higher than model 1 . The infill walls enhanced the stiffness by $40.78 \%, 18.47 \%$, and $41.15 \%$ for models 1,2 and 3 , respectively. Hence, it is found that drops and edge beams have a considerable impact on enhancement of overall stiffness of the structure. The infill walls greatly induced stiffness into the structure.

\section{CONCLUSION}

The following conclusions are made based on the results obtained by pushover analysis,

1. The flat slab models with edge beams are found to be highly stiff and exhibit better performance. 
2. The infill walls in building models with drops increased the ductility of the structure, while it is the reverse in case of other two models.

3. The ductility ratio of the structure should be maintained to be in the range of 4 to 6 . However, the drops, edge beams and infill walls reduced the ductility by making the structure extremely stiff. Hence, measures should be taken to maintain the ductility of the structure.

4. The maximum number of critical hinges was formed at interior columns. The columns from foundation to the level of plinth showed a critical hinging pattern.

5. The performance point was found in the range of life safety to collapse prevention level. The displacement of model 3 was the least at performance point.

\section{REFERENCES}

[1] Agarwal, P. and Shrikhande, M. (2006), "Earthquake design of structures" Prentice Hall of India Private Limited New Delhi India.

[2] Das, D. and Murty, C. V. R. (2004), "Brick masonry Infills in Seismic Design of RC Framed Buildings (Part 2)", The Indian Concrete Journal pp 31-37

[3] Rihan, M., "Seismic evaluation of multistorey buildings with soft storey", M.tech Thesis - 2013.

[4] Praveen, R. and Dyavanal, S.S. (2014), " Non-linear static analysis of $\mathrm{G}+6$ storeyed RC buildings with openings in infill walls", IJERA, ISSN: 2248-9622, Vol. 4, Issue 9, pp51-58.

[5] Agarwal, P. and Shrikhande, M. (2006), "Earthquake design of structures" Prentice Hall of India Private Limited New Delhi India.

[6] Applied Technology Council, ATC 40,(1996), "Seismic evaluation and retrofit of concrete buildings", Vol.1 and 2, California.

[7] FEMA 356, 2000 "Pre-standard and commentary for the seismic rehabilitation of buildings", ASCE for the Federal Emergency Management Agency, Washington, D.C.

[8] Federal Emergency Management Agency, FEMA-440 (2005), "Improvement of nonlinear seismic analysis procedures", California.

[9] FEMA 454: 2006, "Designing for earthquakes: A manual for Architects", December 2006.

[10] FEMA 273: 1997, “NEHRP guidelines for the seismic rehabilitation of buildings"

[11] ETABS 2013 V13.2, "Extended three-Dimensional Analysis of Building Systems", CSI, America.

[12] IS 456:2000, "Code of Practice for Plain and Reinforced Concrete", Bureau of Indian Standards, New Delhi, India.

[13] IS 1893 (Part 1): 2002, "Indian Standard Criteria for Earthquake Resistant Design of Structures", Bureau of Indian Standards, New Delhi 110002.

[14] IS 13920:1993, "Code of practice for plain and Reinforced Concrete", Bureau of Indian Standards, New Delhi, India.

[15] Park, R. and Paulay, T. (1975), "Reinforced concrete structures," Christ church, New Zealand, Aug, pp. 270343.
[16] Dhananjay, D.J. and Pranesh, B.M. (2013), "Performance of flat slab structure using pushover analysis", IOSR Journal of Mechanical and Civil Engineering (IOSR-JMCE), Volume 8, Issue 3 (Sep. Oct.), pp 41-44.

[17] Sahana Ponnamma, T.D., Santhosh, D. and Prabhakara, R. (2015), "Comparative study of pushover analysis of the conventional slab system with outrigger and flat Slab system with outrigger", International Journal of Innovative Research in Science, Engineering and Technology Vol. 4, Issue 8.

[18] Gouramma, G. and Jagadish, K.G. (2015), "Seismic Performance of Different RC Slab Systems for Tall Building", International Journal of Engineering Research, Vol.3., Issue.4.

[19] Anuj, B. and Aditi, P. (2016), "Pushover Analysis of Multi-storey Buildings Having Flat slab and Grid slab", International Journal of Engineering Science Invention Research \& Development; Vol. II Issue VII.

[20] Amit, A. S., Deotale, R.S. (2012), "Analysis and Design of Flat Slab and Grid Slab and Their Cost Comparison"; Vol. 1, Issue 3, pp.837-848.

[21] Mehmet, I., Hayri, B.O. (2006), "Effects of plastic hinge properties in nonlinear analysis of reinforced concrete buildings", Science Direct, Engineering structures 28 . 